\title{
Article \\ Jews, Muslims and the Ritual Male Circumcision Debate: Religious Diversity and Social Inclusion in Germany
}

\author{
Gökçe Yurdakul \\ Department of Diversity and Social Conflict, Humboldt University of Berlin, 10099 Berlin, Germany; \\ E-Mail: gokce.yurdakul@sowi.hu-berlin.de
}

Submitted: 30 October 2015 | Accepted: 20 December 2015 | Published: 19 April 2016

\begin{abstract}
On 7 May 2012, the Cologne regional court ruled that circumcising young boys was a form of previous bodily harm (körperverletzung). Although both Muslims and Jews circumcise infant boys as a religious practice, the Cologne court found that the child's "fundamental right to bodily integrity" was more important than the parents' rights, leaving Muslim and Jewish parents under suspicion of causing bodily harm to their children. After heated public discussions and an expedited legal process, legal authorities permitted the ritual circumcision of male children under a new law. However, the German debates on religious diversity are not yet over. On the third anniversary of the Court decision in 2015, thirty-five civil society organisations organised a rally in Cologne for "genital autonomy", calling for a ban on ritual male circumcision. In this article, I will focus on religious diversity, which is undergoing changes through minority and immigrant claims for religious accommodation. Analysing the ongoing controversies of ritual male circumcision in Germany, I argue that this change is best observed with Muslim and Jewish claims for practicing their religion. By using political debates, news reports and information provided by lawyers and medical doctors who were involved in the public debate, I show that religious diversity debates are a litmus test for social inclusion: Muslims and Jews, in this context, are both passive subjects of social inclusion policies and active participants in creating a religiously diverse society in Germany.
\end{abstract}

\section{Keywords}

Germany; Jews; Muslims; religious diversity; ritual male circumcision; social inclusion

\section{Issue}

This article is part of the issue "Religious Diversity and Social Inclusion", edited by Gary Bouma (Monash University, Australia).

(C) 2016 by the author; licensee Cogitatio (Lisbon, Portugal). This article is licensed under a Creative Commons Attribution 4.0 International License (CC BY).

\section{Introduction}

On 7 May 2012, a German regional court in Cologne ruled that circumcising young boys was a form of bodily harm (körperverletzung). Although both Muslim and Jewish families circumcise infant boys as a religious practice, the Cologne court found that a child's "fundamental right to bodily integrity" superseded the religious rights of parents. This potentially rendered Mus$\mathrm{lim}$ and Jewish parents under suspect of causing bodily harm to their children. After heated public discussions, international political pressure, and a speedy legal process, the regional court ruling was replaced by a new national German law that permitted the ritual circum- cision of male children. Despite the national law, male circumcision continues to be a highly contested issue. On 7 May 2015, thirty-five civil society organisations organised a rally in Cologne for "genital autonomy", calling for a ban on ritual male circumcision, as this practice continues to be an integral part of Jewish and Muslim lives in Germany in the shadow of political and legal challenges.

In this article, I will focus on the role of the German debate on ritual male circumcision in shaping religious diversity. Although religious diversity has been defined in multiple ways, ranging from demographic description of a society to institutional recognition of religious minority groups, I will focus on the aspect of social in- 
clusion of religiously diverse groups in institutional settings (Bouma, Ling, \& Pratt, 2010; Vertovec \& Wessendorf, 2006;). I aim to show relations between two religious minority groups who make claims to the German state authorities in order to practice ritual male circumcision-an act that challenges the norms of German society.

As a key aspect of social inclusion, religious diversity is undergoing contested changes through minority and immigrant claims for religious accommodation (Koopmans, 2013; Vertovec \& Wessendorf, 2006). I argue that this change is best observed by analysing Muslim and Jewish claims for practicing their religion, and how these claims get taken up in public debates. Jews and Muslims in Germany have collaborated in bringing similar claims for religious practices in the past, such as in the case of pointing out to the parallel dynamics of anti-Semitism and anti-Muslim racism in Germany. This does not mean, however, that both communities collaborate on religious diversity claims. Jews and Muslims in Germany also have important fault lines, which divide both communities, which I have elaborated elsewhere (Yurdakul, 2010).

Using discourse analysis of political debates, newspaper reports, focus group interview with Muslim men as well as meetings ${ }^{1}$ with key informants in the public debate, I show how religious diversity debates are a litmus test for social inclusion: How to socially include minority groups if their religious practices are conflicting with the norms of a majority society? The decisive point here is whether or not minority groups are considered as "full members" or "foreigners" in a given society. In this context, I suggest that Muslim and Jewish groups are both objects of social inclusion policies and active participants in negotiating religious diversity, thereby playing both passive and active roles in the shaping of a socially inclusive German society.

\section{Who has the Right to Decide on the Limits of Religious Diversity?}

Political and legal authorities make institutional arrangements in order to accommodate religious diversity (Bramadat \& Koenig, 2009; Giordan, 2014). The regulation of religious diversity is often defined in a top-down manner, such as through government policies. European institutions, such as national and European-level Courts, act as authorities for playing important roles in shaping what kind of practices of religious diversity are permissible in the European public sphere (Greenfield, 2013; Koenig, 2007). However, religious groups, in this case Jews and Muslims in Ger-

\footnotetext{
${ }^{1}$ These are meetings rather than interviews, because our conversations did not have traditional interview structure in a sociological sense. In addition, I had the chance to ask questions to some of them in public meetings.
}

many, challenge these regulations in their everyday lives (Kastoryano, 2002; Laurence, 2001; Peck, 1998). Despite the top-down legal decision-making process, many Jewish and Muslim groups may continue practicing their religions and as a result they may be excluded from social institutions ${ }^{2}$.

\section{Stigmatisation of Jews and Muslims}

Ritual male circumcision is the practice of removing the foreskin of a new born or prepubescent male child (Gollaher, 2000), and is a practice mainly associated with Jewish and Muslim religious traditions. The political significance of the ritual stems in part from the fact that it is irreversible, and as argued by some legal, political, and medical authorities and scholars, it is considered a major infringement of children's rights to bodily integrity (Schüklenk, 2012). While circumcision is a gendered practice that permeates across minority religious groups in many European countries, social service agencies, legal institutions, and other state-related institutions, such as hospitals, have a limited understanding of the practice itself. For these social actors, circumcision is often understood as a sign of cultural backwardness, and in some cases as an act of violence against male children. These understandings of circumcision as evidence of violence and backwardness-instead of as contested faith-based practices for example-are produced by reifying minority cultures as monolithic traditions marked by their inherent ignorance of children's well-being (Benatar, 2013; Lang, 2013).

Scholars have examined the body politics of Jewish histories in secular Europe. Sander Gilman discusses the stigmatisation of the Jewish body through medical constructions in his work on The Jew's Body (1991). He explains how the rhetoric of modern science marks the Jewish body as different. Gilman shows how modern medicine, as a discursive agent of secular authorities, stigmatises the Jewish body by disseminating it to its parts (such as the infamous Jewish nose) and describing it as deviant from "the norm". Law and medical sciences distill and embody non-Muslim and non-Jewish values i.e., those of Christian or, at least, liberal Christian values. Similarly, the Muslim body politics in Europe is about how Muslim bodies are marked as different and are excluded from the European public sphere (Korteweg \& Yurdakul, 2014; Lettinga \& Saharso, 2014). Drawing on such work on Jewish and Muslim bodies, I aim to show how discursive agents, such as legal authorities, newsmakers, and key political stakeholders try to shape minority bodies, those of Jews and Muslims, in Europe. I will focus on two major areas where secular discourse prevails (namely, science and

\footnotetext{
2 For Muslims, primarily from educational institutions and job market, such as in the case of Muslim women's headscarves (Korteweg \& Yurdakul, 2014).
} 
law) exceptionally present in Germany, which marks the limits of religious diversity and the borders of social inclusion into German society.

This study also contributes to ongoing scholarly discussions about ritual male circumcision among legal scholars, bioethicists and sociologists. I argue that many legal scholars fail to adequately look into the perspectives of minorities themselves, and instead simplify debates on rights and obligations (Merkel \& Putzke, 2013). Criminalising religious practices through law enables governing authorities to gain greater control over minority religious practices. This focus on legal aspects presents us from understanding the performative effects of religious diversity. In other words, I suggest that we look at how the law affects people, rather than just law in books. In this article, I examine the German court decision in 2012, but also delve into how social actors discuss the outcomes of the legal debates. My analysis of the circumcision debate considers factors such as Jewish history in Germany as a potentially important contextual factor that affected the decisionmaking process in $2012^{3}$.

By drawing on this contextual framework, as a sociologist, I focus on the majority-minority power relations and the interrelations between two minority religious groups in this debate. I do this by reconstructing how key stakeholders talk to each other in the public sphere by referring to their own political positions. In these discussions, we find how Muslims and Jews are both objects of German social inclusion policies, but also active participants of how to create a religiously diverse society in Germany. In the following, I will discuss the historical context of the circumcision debates and link them to current media and political controversies. My fieldwork in public discussions, focus group interview and meetings with key stakeholders shows how religious diversity is discussed within minority groups.

\section{Historical Context}

The 2012 circumcision debate in Germany was not the first debate on religious diversity within German context. It has persisted throughout history in relation to the particular traditions of Jews in Germany (Judd, 2007; Kokin, 2014; Lavi, 2009). With the incoming flux of immigrants from Muslim countries, most notably Turkish immigrants and their eventual settlement in Germany, this revived the debate on ritual slaughtering $^{4}$ (Lavi, 2009; 2010) and ritual male circumcision ${ }^{5}$

3 This contextual analysis of the circumcision debate, which brings social factors into the debate, is present in some recent legal scholarship (Fateh-Moghadam, 2012).

${ }^{4}$ Turkish butcher Rüstem Altinküpe brought the case of ritual slaughter to the court, and won his case in 2006 (Jüdische Allgemeine 1.10.2009). Halal slaughtering of meat is permitted in Germany under restricted conditions. For Jewish and Muslim
(Yurdakul, 2013). As we shall see, the stigmatisation of minorities remains constant during these discussions, regardless of the outcome.

The history of debates around circumcision prior to the 2012 law has been detailed in a book, Contested Rituals by historian Robin Judd (2007). She describes the political and social circumstances of Jewish life in Germany and shows how exclusionary approaches can be found in the writings of German scholars since the turn of the century. These writings have been stigmatising Jewish ritual behaviours for centuries, from defaming their masculinities to pointing out ritual practices as barbarism (Judd, 2007; see also Heil \& Kramer, 2013). Although this debate on circumcision took place in another socio-political period in the $19^{\text {th }}$ century, it is interesting to see that some of the political actors (medical doctors, state attorneys and Jewish community leaders) and the theme (circumcision ban) similarly take front stage. In terms of stigmatisation, Judd quotes the example of a ritual male circumcision case in Baden in 1881. The state medical examiner, named E. Sausheim, argued that the mohel (circumciser) should be suspended and the oral suction (metistsah be'peh) should be outlawed (Judd, 2007, pp. 1-2).

The use of science and law to exclude Jewish religious practices have been exemplified in Sander Gilman's brilliant essay in Haut Ab!, the Jewish Museum's temporary exhibition catalogue on the ritual male circumcision (2014-15). He states that "No medical circumcision discussion had been independent from ideological perspective" (2014, p. 123, translated from German). He points to the unproven discussions on whether circumcision can be a cure for syphilis or cervical cancer, or even HIV. In some cases, newsmakers make blanket statements on sexual impotency of circumcised men (Stehr, 2012). In the context of these discussions, Sander Gilman concludes that at the end of all these debates the decisive factor is not science, but cultural acceptance (Gilman, 2014). In fact, in assimilatory efforts of Jews into German social and cultural life, in 1843 in Frankfurt, a liberal group of Jews, including Rabbi Abraham Geiger, who was the leading figure of Reform Judaism in Germany, wanted to abandon ritual male circumcision, arguing that it was barbaric (Gollaher, 2000).

Muslim immigrant integration and criminalisation of Muslims mark a shift in the current debates. Sander Gilman questions why the ritual circumcision debate came back onto the political agenda in Germany and even beyond, such as in Scandinavian countries or in Britain where it is still contested and performed under restricted conditions. He argues that this has a lot to do

ritual slaughtering in Germany (see Lavi, 2009).

${ }^{5}$ As I will discuss in the following pages, ritual male circumcision is permitted in Germany after a court case in 2012, but it is practiced under restricted conditions. 
with the "fear of Islamisation" (Gilman, 2014, p. 125), as Islam is frequently regarded by newsmakers and politicians as a religion that is not compatible with German society, and Muslims have difficulties in being socially included into the German way of life.

\section{Method}

The data for this article has been collected from various media resources, legal documents, participant observations, meetings with key stake holders and focus groups. The legal data was collected from Court decisions and press releases of the Cologne local and regional courts (Amtsgericht and Landgericht) as well as the decisions and public statements of the German Ethics Council, which are available on their website.

The media data is from three German newspapers that spanned the political spectrum since the beginning of the legal circumcision debate on 26 June 2012 to 31 December 2014, when the circumcision debate was ongoing on a smaller scale. I collected all the articles that discussed "circumcision" from their online archives, sorting out those on female circumcision, or circumcision debates in non-Western countries to refine the sample ${ }^{6}$. The German newspaper data was collected from three major sources: Süddeutsche Zeitung (SZ), tageszeitung (taz) and Frankfurter Allgemeine (FAZ). I chose these three newspapers in order to cover the political spectrum in the German media. SZ appeals to a left-liberal readership, FAZ is a conservative newspaper, taz is a left-leaning newspaper, showing the perspectives of the Green Party ${ }^{7}$. For all these newspapers, I created a chronology of events, which documented what has been discussed in each newspaper on a weekly basis. In addition to the systematic data collection from these German daily newspapers, I also used newspaper articles from Jüdische Allgemeine 8 , a weekly newspaper of the Central Council of Jews; der Spiegel, a popular weekly magazine, die Zeit, a high-brow weekly newspaper, as well as the European edition of the Turkish national newspaper, Hürriyet.

In addition to media data, the study also includes data from a focus group and four meetings with key stakeholders. The focus group participants were four Turkish Sunnite Muslim men, all of whom reside in

\footnotetext{
${ }^{6}$ In this time period, hundreds of newspaper articles appeared in the newspapers, for example in the FAZ there are 352 mentionings of words Jewish and circumcision whereas 181 mentionings of Muslim and circumcision. In the SZ, such words appeared 370 to 186 and in the taz 248 and 160 . These articles are only about male circumcision.

$7 \mathrm{SZ}$ has the highest circulation at 1.1 million per day. FAZ has an estimated circulation of almost 400 thousand, taz has the lowest circulation among all, about 60 thousand.

8 I thank Zülfukar Çetin for opening his newspaper archive for the missing resources.
}

Germany ${ }^{9}$. All of these men were circumcised as children either in Turkey or in Germany and they discussed how they are affected by the ongoing circumcision debate. I met with key informants who were active in the circumcision debate: Ilhan Ilkilic, MD, a member of the German Ethics Council who drafted the circumcision law; Mustafa Yeneroglu, lawyer and the previous head of the Islamic Community of Milli Görüs, who politically supported the legal case of male circumcision in Germany; and Zulfükar Çetin, co-author of the controversial book on circumcision, Interventionen gegen die deutsche "Beschneidungsdebatte" (Interventions against the German "circumcision debates"). This book was cited frequently in the German circumcision debates in order to exemplify minority men's perspective. A final informant for this research was Felicitas Heimann-Jelinek, the curator of the Jewish Museum exhibition on circumcision. I had the chance to directly ask her questions during a closed meeting within Jewish-Muslim Study Group at the Jewish Museum in December 2014.

\section{Social Inclusion, Exclusion and Religious Diversity}

The peak of the circumcision debate was the Cologne regional court's decision on 7 May 2012, which criminalised Jewish and Muslim parents for causing bodily harm to their children. The German public was divided into two groups: those who were pro-ban of circumcision argued that (1) the right of self-determination of the child is violated, (2) the circumcision is irreversible and irreparable. Without reason a child loses a healthy part of its body, (3) the surgery is dangerous to the human body like every other surgery, and (4) circumcision is only reasonable in those cases where it is medically indicated. Those who are against the ban argued that the exercise of parental care of $\S 1627$ । BGB (German Civil Code), covers all of the parents' decisions as long as they benefit the well-being of the child. The main argument of those who are against the ban is that excluding a child from the religious group is against the child's well-being. This is justified as parents are prevented from passing on their values and beliefs to their children.

A major finding from my discourse analysis is that, "child's well-being" is vaguely defined, and is usually concealed under "child's right to bodily integrity" or "child's right to self-determination". For example, in its legal decision, the Cologne Regional Court concluded that:

"Neither is the request of the parents capable of justifying the act, since the right of the parents to

\footnotetext{
${ }^{9}$ Due to the gender sensitivity of the subject, this focus group interview was solely conducted by my assistant Mr. Özgür Özvatan, at the Humboldt University of Berlin.
} 
raise their child in their religious faith does not take precedence over the right of the child to bodily integrity and self-determination. Consequently, the parental consent to the circumcision is considered to be inconsistent with the well-being of the child." (Landgericht Köln, 151 Ns 169/11) ${ }^{10}$

In this legal statement "children's well-being ${ }^{11 "}$ is constructed through an individualistic understanding of the child, isolated from their parental social context who are minorities. In fact, in a similar logic, medical doctor Matthias Franz, an opponent of circumcision, argues that "In this context, religious freedom cannot be a justification for (sexual) violence against young boys, who are unable to consent" (Franz, FAZ, 21.7.2012). In this case, German legal and medical authorities, rather than Jewish and Muslim parents, decide on behalf of the child who cannot give consent. In other words, children's well-being is best decided by the state authorities, as practices of religious diversity are not acceptable when it comes to minority parents.

One such argument along the same lines is that circumcision is a form of stigmatisation of children, because they cannot reverse the operation. The aforementioned court decision on the circumcision:

"Moreover, the circumcision changes the child's body permanently and irreparably. This change runs contrary to the interests of the child in deciding his religious affiliation independently later in life. On the other hand, the parental right of education is not unacceptably diminished by requiring them to wait until their son is able to make the decision himself whether to have a circumcision as a visible sign of his affiliation to Islam." (Court decision from 7 May 2012; Landgericht Köln, 151 Ns. 169/11)

The marking of the body for a sign of belonging to Islam or Judaism is further interpreted as stigmatisation: "This is also a way to prevent a threatening stigmatisa-

10 This English-translation is available at the https://www. dur.ac.uk/resources/ilm/CircumcisionJudgmentLGCologne7Ma y20121.pdf

11 "Children's well-being" appears as a nebulous concept in policy-making and in legal discussions. According to the UN Convention on the Rights of the Child: "In all actions concerning children, whether undertaken by public or private social welfare institutions, courts of law, administrative authorities or legislative bodies, the best interests of the child shall be a primary consideration" (1990, Article 3). This statement may involve excessive statism (state authorities deciding on behalf of parents) but also discrimination against certain minorities (state authorities prohibiting Islamic rituals). However, it is noted that circumcision is irreversible and the child must decide later himself if he belongs to Islam. This statement of the Landgericht Köln brings Islamic practices under spotlight. tion of the child" (Court decision from 21 September 2011; Amstgericht Köln, 528 Ds 30/11). The discourse on stigmatisation of children has already been mentioned in criminal law scholar Holm Putzke's above mentioned statement, namely that the less parents circumcise their children, the less stigmatisation will take place. I argue that such an approach does work from a political point of view as it holds Muslim and Jewish parent responsible for the stigmatisation of their children and their exclusion from German society. In earlier works, Holm Putzke at the University of Passau, argued for the criminalisation of circumcision in Germany: "For the more frequently boys are not circumcised, the less this condition, this gives reason for stigmatisation" $(2008$, p. 21$)$ in this way dividing Germany into circumcised and uncircumcised people.

Similarly, anti-circumcision debates were picked up by immigrant political actors even before 2012. Turkish-German sociologist and Islam-critic Necla Kelek brought up the issue in a German Islam Conference and also wrote about the possible harms of ritual male circumcision in her book Lost Sons (Kelek, 2006). Being a pro-ban advocate only for Muslim circumcision, Kelek differentiated between Jewish practices of circumcision, and the Muslim practice. According to her, Jewish practice is based on religion (therefore should be permitted), whereas the Muslim practice is merely a tradition (and therefore should be banned). In this way, Kelek argued that only religious acts have the potential to be legally permitted in Germany, disregarding other arguments such as a child's well-being.

The German media was divided in the debate. On the one hand, newsmakers gave public voice to medical authorities, religious clergy, legal authorities and scholars who are mostly pro-ban. German newspapers, such as FAZ, die Welt or weeklies, such as der Spiegel, were quick to publish photos of rabbis practicing circumcision ceremonies. They used provocative headlines, such as "Ritual, Trauma, Kindeswohl" (Ritual, trauma and well-being of the child), "Auch die Seele leidet" (The soul also suffers), "Freiheit ist wichtiger als Tradition" (Freedom is more important than tradition).

Those who are anti-ban were featured in mainstream newspapers but mostly writing editorial pieces for the minority newspapers, such as Jüdische Allgemeine or Hürriyet. Both Central Council of Jews and Islam Council reacted immediately grounding their arguments in different social and historical facts. Ali Kizilkaya, the executive director of Islam Council drew on to the integration debates and argued that Cologne Court's pro-ban decision is against Muslims efforts to integrate into Germany. Dieter Graumann, the previous Chairman of the Central Council of Jews in Germany argued that this decision makes Jewish life in Germany impossible. Although the Court decision was about the specific case of a Muslim boy, the politicians and newsmakers started focusing on Jewish circumci- 
sion in Germany, with central figures of the Jewish community in Germany as well as the Chief Rabbi from Israel, commenting on the legal decision. Newsmakers in the European edition of Hürriyet were not so concerned about the decision, perhaps because Turkish communities in Germany have been confronted with such religious bans in the past, such as that of the headscarf debate. The circumcision issue carried second or third rate importance in their reporting. Some reporters mentioned travelling outside of Germany to carry out circumcisions, where families may take children to Turkey, if it were to be banned in Germany.

At this same time, there were those who were antiban, but were not represented in the media discussions. Social workers who are embedded within Muslim societies in Berlin claimed that they were excluded from the debates. Although they were coming from migrant families and had face-to-face contact with many Muslim families as part of their job, no journalist quoted their thoughts about the circumcision debate. Their voices went unheard, despite the fact that they were frontline social workers. In my meeting with ZüIfukar Çetin, at that time a social worker at the antiracist organisation Reach Out, he told me he felt excluded, he mentioned that no one asks the youth in the Berlin district of Kreuzberg about what they think, even though they are the subjects of the debate. In his book co-authored with Alexander Salih Wolter, Çetin pointed out that the debate polarised men as "circumcised" and "uncircumcised," therefore creating multiple forms of masculinities, which are in competition with each other. They argued that the so-called "Judeo-Christian tradition of the West" is paradoxically referring to Jewish traditions as crimes and therefore anti-Semitic in itself. This paradox reached its highest point in the circumcision debate, in which anti-Muslim racism accompanies anti-Semitism (Çetin \& Wolter, 2012, p. 39). Both groups, they argued, were excluded from being members of German society due to their religious practices.

Another key actor in the debates was the German Ethics Council, a government agency which was responsible for making recommendations for drafting the 2012 circumcision law. The Ethics Council made an anti-ban decision and made suggestions to the legal authorities to draft the new circumcision law. In our meeting ${ }^{12}$ with Ilhan Ilkilic, MD, a member of the German Ethics Council, he stated that the Ethics Council decided according to the presumption that religious freedom is seen as a more important liberal value than bodily integrity of children ${ }^{13}$ (also see Ilkilic, 2014). Ac-

12 Yurdakul and Lavi meeting with Ilhan Ilkilic, 22.1. 2015, Berlin.

13 Ilkilic mentions in an interview: "In my view religious freedom is more important than the violation of physical integrity, because the practice does not alter the function of the organ, if cording to the Ethics Council's suggestions for regulating male circumcision, a child's consent would still be important in conducting the circumcision; religious circumcisers can practice circumcision on children only until the 8th day, after this day medical personnel would be responsible for circumcision. The Ethics Council's draft law was passed to the Bundestag. With this law, Muslim and Jewish practices of religious diversity became lawful, implying that Muslims and Jews are socially included into the religious life in Germany.

However, a member of the Ethikrat (Ethics Council) was against the law altogether. Reinhard Merkel argued against the practice of circumcision on the grounds that there is no obligation under the law to take the consent of the child and no obligation for anaesthesia (Die Zeit, 1 October 2012). In fact, Merkel had previously pointed out the ethical, legal and historical problems of this decision earlier, by stating that: "No right to freedom permitted an interference with the body of a human. This is also true for circumcision in boys. And yet the case is difficult" (SZ, 30.8.12). He especially pointed to the fact that Jewish history in Germany has played an important role in passing this decision:

"If an unknown religious group were to come to Germany today with the ritual of male circumcision, common in no other place of the world, it would be prohibited on the spot. And if it was solely Muslim religious practice, the Bundestag certainly would not have responded to the Cologne judgement with a resolution as on the 19 July. But circumcision is an ancient custom constitutive of Judaism. And that's the real problem of legal policy. Hiding this fact is useless; because only with this provenance its significance is clear. The terrible mass murder in history makes German Politics certainly most prominent and unique duty to show particular sensitivity to all Jewish matters. This cannot be shaken. Circumcision is obviously a matter of particular importance." (Merkel's commentary in the Süddeutsche Zeitung, 30.8.2012)

In fact, in this statement, Merkel says that Jewish and Muslim religious practices, such as circumcision, cannot be included into German social life. Due to the German responsibility towards Jews, the law was passed. This statement, I argue, shows how Jews and Muslim are still not considered as a part of German society, but as "foreigners". If Germans were not fulfilling their responsibility towards Jews in the frame of "wiedergutmachen" (to redress), the law would not be passed. Merkel implies that such religious practices would not belong to

the operation is carried out safely and correctly. And in addition, a ban puts huge pressure on Muslims because circumcision represents an important ritual for them." (Ilkilic, 2013) 
German society under normal circumstances. As Sander Gilman showed cultural acceptance of religious practices is the decisive factor in social inclusion (2014). In this case, Jewish and Muslim ritual of male circumcision is still a contested practice, despite the fact that it can be legally practiced in Germany.

The debate spread to international media, yet the importance given to the debate, especially in Israel and Turkey, varied. In the Israeli daily newspaper, Haaretz, the circumcision debate was a daily discussion. The European Rabbis Conference (Europäische Rabbinerkonferenz) was cited in the German newspapers: "The ruling is seen as the most serious attack on Judaism since the Holocaust." (SZ, 16.7.2012). The Chief Rabbi of Israel Yona Metzger came to Germany to discuss the issue with politicians and to hold a press conference in the hall of the Federal Press (Bundespressekonferenz), addressing the national and international media, and warning against anti-Semitism in Germany (taz, 21.8.2012). Similarly, President Shimon Peres sent a letter to the German President Joachim Gauck, asking him to intervene to safeguard the religious rights of Jews in Germany (SZ, 25.8.2012). In Turkey, the possible ban on circumcision did not find much political resonance. Turkish citizens carried out some independent campaigns to protest the legal decision (Tosun in Hürriyet, 29 June 2012).

During these discussions, Chancellor Angela Merkel has personally followed the circumcision debate. In fact, she infamously said: "I do not want Germany to be the only country in the world where Jews cannot practice their rituals. Otherwise, we turn into a laughing stock (komiker nation)"14. This shows her support to pass the circumcision law without causing more damage to Germany's international image (FAZ, 17.7.2012). Just before the passing of the law, she paid a political visit to the Central Council of Jews in Frankfurt, where she said that Germany shows tolerance to religions (FAZ, 25.11.2012). On 12 December 2012, approximately 6 months after the debate in Cologne, the Bundestag adopted the proposed law explicitly permitting male circumcision to be performed under certain conditions ( $\$ 1631(d)$ part of the German Civil Code (BGB)), making ritual male circumcision a lawful religious practice in Germany.

\section{A One Way Street: Inclusion into a Minority, but Exclusion from a Majority}

As political scientist Kerem Öktem mentions in his study on "Signals from the Majority Society," in which

${ }^{14}$ This is the translation in the National Post on 17 July 2012. The German original is cited as follows: "Ich will nicht, dass Deutschland das einzige Land auf der Welt ist, in dem Juden nicht ihre Riten ausüben können. Wir machen uns ja sonst zur Komiker-Nation." (Jones, 2012) he interviewed Jews, Muslims and Germans on the circumcision debate during these discussions in Germany, both Jewish and Muslim interviewees clearly stated that they felt that they are excluded from European societies as their religious practice and male bodies are criminalised and stigmatised (2013). In fact, in a focus group interview that we conducted with four religious Turkish and Sunnite Muslim men, we also heard many times that their circumcised male body is an integral part of their minority identity (see also Kokin, 2014). For example, in the focus group interview, Ali (pseudonym) said "being circumcised is a form of belonging. It is a part of being a man". Similarly, Tarik mentioned that he would find it shameful if a man is not circumcised. Our focus group participants discussed how being circumcised is an in-group identity marker for a minority group in Germany, that is striving to belong. In fact, this finding was also evident in other public testimonials by Turkish men, such as the co-leader of the Green Party and a prominent politician of Turkish background, Cem Özdemir, who wrote about how his relationship with his body gives him an in-group recognition and a feeling of belonging (2008, pp. 235-238).

A key finding in our focus group involved the shared identity markers among Muslim and Jewish groups that practices of circumcision engendered. One participant claimed that male circumcision is a bodily marker, which binds Jews and Muslims in Germany. Hasan said "In Judaism, in Torah it is definitely in it (in their religion). I mean...When we are all circumcised, then 'hey! You are also circumcised!'... find it positive. Normal. You are also one of us ${ }^{15 "}$. Hasan is pointing to circumcision as an identity marker for both Jews and Muslims in Germany, a constitutive marker of their minority belonging.

Although some men, like the focus group participants, consider circumcision as a form of social inclusion, in the sense that it is belonging to a minority group in Germany, it is also regarded as a marker of social exclusion by many German legal, medical and political authorities. These groups express concern over whether granting freedom of religion to immigrants and minorities would cause social disintegration or not.

Reflecting on the minority perspectives on the debate, the Jewish Museum in Berlin organised an exhibition and a series of events. Focusing on the inclusion/ exclusion dichotomy in a playful way, the title of the exhibition, called Haut Ab!, which was intended as a pun on the German term, "skin off!" or "get out!" Speaking to Felicitas Heimann-Jelinek, the curator of the exhibition ${ }^{16}$, she aimed to contextualise the con-

\footnotetext{
15 In the framework on minority belongings, in our book on the headscarf debates, we focus on the ways in which Muslim women use the headscarf as a method of protest and asserting national belonging (2014).

${ }^{16}$ Meeting with Felicitas Heimann-Jelinek in the Jewish Muse-
} 
troversial circumcision debate historically. At the same time, the exhibition showed the religious diversity of male circumcision practices, varying from photos of crying boys from Turkish immigrant families in order to reflect the contemporary history of ritual male circumcision in Germany, to videos on Jewish life in Germany.

A panel of scholars presented at an event on Jewish-Muslim relations, organised with the Haut $A b$ ! exhibition on 4 December 2014. The panel included historian Alexander Hasgall, political scientists Mounir Azzaoui and Kerem Öktem, as well as Hannah C. Tzuberi, a scholar of Judaism and Islam. It was emphasised that the circumcision debate in Germany brought Jews and Muslims together as minorities who have been struggling for their practices of religious diversity to be socially included as minorities. Referring to a public poll that was conducted by a polling agency, Infratest, the academic director of the Jewish Academy Yasemin Shooman stated that $70 \%$ of German society was against the circumcision law (also see HeimannJelinek \& Kugelmann, 2014). She questioned whether there is any protection of minorities in this context that their practices of religious diversity are clearly socially excluded.

With the introduction of the circumcision law, the debate on legal recognition and regulation of male circumcision in Germany seemed to be over. But German criminal lawyers have argued that section $1631 \mathrm{~d}$ BGB is against the constitution ${ }^{17}$, and are preparing to continue the debate, with the support of some medical doctors. On 3 June 2015, the Elisabeth Hospital in Essen organised a conference on medical and legal perspectives on the circumcision debate. The conference included medical doctors who have been publicly active against circumcision. They argued that: "surgery in the genital area of a little boy means a painful and traumatic experience, which therefore should be considered independent of its implications" (Liedgens \& Eckert, 2015). In short, the male circumcision debate is continuing to legalise and medicalise discourses in order to criminalise and pathologise Jewish and Muslim religious practices, leaving little opportunity to discuss religious diversity in a socially inclusive society.

\section{Conclusion}

Ritual male circumcision, a latent subject of discussion for many years, has returned to the Western secular political agenda (for a historical debate see Judd,

um on 20 January 2015 in the framework of the JewishMuslim Study Group, led by Nilüfer Göle and Amnon RazKrakotzkin.

17 Bürgerliches Gesetzbuch (BGB) § 1631d Beschneidung des männlichen Kindes (German Civil Code, Circumcision of Male Children), http://www.gesetze-im-internet.de/bgb/_ _1631d.html (accessed on 15 April 2015)
2007). The circumcision debate is, in fact, not a uniquely German debate, but it is a discussion on who has the authority to decide on body politics in Europe and in the rest of the Western countries, where Jews and Muslims are still considered strangers. Social inclusion, which is determined by legal authorities through court decisions, political actors and scholars, as well as media discussions, show how Jewish and Muslim religious practices are still discussed in the contexts of public threat and stigmatisation. The language that has been used in legal decisions and in the media have deeply stigmatised and criminalised Jewish and Muslim people in this context.

The purpose of this article is not to endorse ritual male circumcision, but rather to show how social inclusion and exclusion of minorities are decided in public debates through local courts, media debates, and scholars' press statements. Ritual male circumcision is one significant case, which shows different dynamics of what plays a role in determining religious diversity in order to socially include minorities. My suggestion for further analysis is to critically look at how social actors of minority groups challenge the existing socio-legal discourses through their religious practices and bodily performances. A systematic research agenda, which focuses on how legal decisions are interpreted and debated by minority groups, will enable us to see who belongs to Germany and Europe and what will shape German and European futures.

\section{Acknowledgments}

Earlier versions of this work were presented in the working group for " A Shared Perspective of Jews and Muslims for Europe Comparative Perspective on Issues of Cultural Practices and the Secular Public Sphere: The Example of "Male Circumcision" in Istanbul Policy Center (2014) and in the Jewish Museum in Berlin (2015). I am grateful to the members of working group, specifically Nilüfer Göle, Amnon Raz-Krakotzkin, Gabriel Motzkin, and Shai Lavi for their comments on earlier versions. I was invited to present this work with an invitation by Dr. Aviad Rubin at the University of Haifa, Department of Political Science (2013). I am grateful to his generosity and feedback from the departmental colleagues. I thank to my colleagues at the Council for European Studies Conference in Amsterdam (2012), especially Anna Korteweg, Liza Mügge and Leah Bassel, and to conference participants at the Sussex Migration Center's 2015 Annual Conference who discussed parts of this work with me. Last but not least, I am grateful to Birgit zur Nieden, Özgür Özvatan, Larissa Probst, Pauline Weller, Salina Abji and Jurek Wolter, who helped with the data collection and writing of this article. My thanks go to Shai Lavi, Esra Özyürek, David Abraham and Nadine Blumer who commented on the final version. The funds to publish this open-access article is 
generously provided by the German-Israeli Foundation Regular Grant (co-investigator with Shai Lavi).

\section{Conflict of Interests}

The author declares no conflict of interests.

\section{References}

Benatar, D. (2013). Evaluations of circumcision should be circumscribed by the evidence. Journal of Medical Ethics, 39(7), 431-432.

Bouma, G. D., Ling, R., \& Pratt, R. (2010). Religious diversity in Southeast Asia and the Pacific. Dordrecht: Springer.

Bramadat, P., \& Koenig, M. (Eds.). (2009). International migration and the governance of religious diversity. Ontario: Metropolis.

Çetin, Z., \& Wolter, S. A. (2012). Fortsetzung einer "Zivilisierungsmission: Zur deutschen Beschenidungsdebatten". In Z. Çetin, H. J. Voß, \& S. A. Wolter (Eds.), Interventionen gegen die deutsche "Beschneidungsdebatte". Münster: Edition Assemblage.

Fateh-Moghadam, B. (2012). Criminalizing male circumcision-Case Note: Landgericht Cologne Judgment of 7 May 2012- No. 151 Ns 169/11. German Law Journal, 13, 1131-1145.

Franz, M. (2012, July 21). Ritual, trauma, kindeswohl. Frankfurter Allgemeine Zeitung (FAZ). Retrieved from http://www.faz.net

Gilman, S. (1991) The Jew's Body. New York: Routledge.

Gilman, S. (2014). Gesundheit, Krankheit und Glaube: Der Streit um die Beschneidung. In F. HeimannJelinek \& C. Kugelmann, (Eds.), Haut ab!: Haltungen zur rituellen Beschneidung, Jüdisches Museum Berlin (pp. 119-129). Berlin: Wallstein.

Giordan, G. (2014). Introduction. In G. Giordan \& E. Pace (Eds.), Religious pluralism: Framing religious diversity in the contemporary world (pp. 1-12). Cham, Heidelberg, New York, Dordrecht, London: Springer.

Gollaher, L. D. (2000). Circumcision: A history of the world's most controversial surgery. New York: Basic Books.

Greenfield, A. K. (2013). Cutting away religious freedom: The global and national debate surrounding male circumcision. Rutgers Journal of Law and Religion, 15(353), 361-363.

Heil, J., \& Kramer, J. S. (Eds.). (2013). Beschneidung: Das Zeichen des Bundes in der Kritik. Berlin: Metropol Verlag.

Heimann-Jelinek, F., \& Kugelmann, C. (2014). Haut ab!: Haltungen zur rituellen Beschneidung. In F. HeimannJelinek \& C. Kugelmann (Eds.), Haut ab!: Haltungen zur rituellen Beschneidung, Jüdisches Museum Berlin (pp. 19-26). Berlin: Wallstein.

Ilkilic, I. (2013, July 4). Inter-religious dialogue on matters of health. Qantara. Retrieved from https://en. qantara.de/content/interview-with-medical-ethicistilhan-ilkilic-inter-religious-dialogue-on-matters-ofhealth

Ilkilic, I. (2014). Islamische Aspekte der Beschneidung von minderjährigen Jungen. Zeitschrift für medizisnche Ethik, 60, 63-72.

Jones, G. (2012, July 17). July German circumcision ban makes nation a 'laughing stock,' Angela Merkel says. National Post. Retrieved from http://news.national post.com/news/german-circumcision-ban-makesnation-a-laughing-stock-angela-merkel-says

Judd, R. (2007). Contested rituals: Circumcision, kosher butchering, and Jewish political life in Germany. Ithaca: Cornell University Press.

Kastoryano, R. (2002). Negotiating identities: States and immigrants in France and Germany. Princeton: Princeton University Press.

Kelek, N. (2006). Die verlorenen Söhne. Plädoyer für die Befreiung des türkisch-muslimischen Mannes. Köln: Kiepenheuer \& Witsch

Koenig, M. (2007). Europeanising the governance of religious diversity? An institutionalist account of Muslim struggles for public recognition. Journal of Ethnic and Migration Studies, 33(6), 911-932.2

Kokin, D. S. (2014). "Der Bund, den Du an unserem Fleisch besiegelt hast:" Beschneidung in jüdischem Denken und jüdischer Praxis. In M. Langanke, A. Ruwe, \& H. Theißen (Eds.), Rituelle Beschneidung von Jungen: Interdisciplinäre Perspektiven (pp. 99-112). Leipzig: Evangelische Verlagsanstalt.

Koopmans, R. (2013). Multiculturalism and immigration: A contested field in cross-national comparison. Annual Review of Sociology, 39, 147-169.

Korteweg, A. C., \& Yurdakul, G. (2014). The headscarf debate: Conflict of belonging in national narratives. Stanford: Stanford University Press.

Lang, D. P. (2013). Circumcision, sexual dysfunction and the child's best interests: Why the anatomical details matter. Journal of Medical Ethics, 39(7), 429-431.

Laurence, J. (2001) (Re) constructing community in Berlin: Turks, Jews, and German responsibility. German Politics \& Society, 22-61.

Lavi, S. (2009). Unequal rites: Jews, Muslims and the history of ritual slaughter in Germany. In J. Brunner \& S. Lavi (Eds.), Juden und Muslime in Deutschland. Göttingen: Wallstein.

Lettinga, D., \& Saharso, S. (2014). Outsiders within: Framing and regulation of headscarves in France, Germany and The Netherlands. Social Inclusion, 2(3), 29-39.

Liedgens, P., \& Eckert, K. (2015). Symposium zur Jungenbeschneidung, Hörsaalzentrum im ElisabethKrankenhaus Essen, 3 June.

Merkel, A. (2012, July 12). Umstrittene Rechtslage: Kanzlerin warnt vor Beschneidungsverbot. Spiegel Online Politik. Retrieved from http://www.spiegel.de/ politik/deutschland/bundeskanzlerin-merkel-warnt- 
vor-beschneidungsverbot-a-844671.html

Merkel, A. (2012, July 17). Gesetzentwurf bis zum Herbst . Frankfurter Allgemeine Zeitung (FAZ). Retrieved from http://www.faz.net

Merkel, A. (2012, November 25). Merkel kritisiert Antisemitismus. Frankfurter Allgemeine Zeitung (FAZ). Retrieved from http://www.faz.net

Merkel, R. (2012, August 30). Die Haut eines Anderen. Süddeutsche Zeitung (SZ). Retrieved from http:// www.sueddeutsche.de

Merkel, R., \& Putzke, H. (2013). After Cologne: Male circumcision and the law. Parental right, religious liberty or criminal assault? Journal of Medical Ethics, 39(7), 444-449.

Münch, Peter. (2012, November 25). Streit um ein göttliches Gebot. Süddeutsche Zeitung. Retrieved from http://www.sueddeutsche.de

Öktem, K. (2013). Signale aus der Mehrheitsgesellschaft. Auswirkungen der Beschneidungsdebatte und staatlicher Überwachung islamischer Organisationen auf Identitätsbildung und Integration in Deutschland. Oxford: European Studies Centre, St. Antony's College. Retrieved from https://tezhamburg.files.wordpress. com/2013/09/signale-aus-der-mehrheitsgesellschaft. pdf

Özdemir, C. (2008). Kulturelle Unterschiede-Kleine Hindernisse. In C. Özdemir (Ed.), Die Türkei: Politik, Religion, Kultur (pp. 235-239), Weinheim, Basel: Beltz \& Gelberg.

Peck, J. (1998). Turks and Jews: Comparing minorities in Germany after the Holocaust. In J. Peck (Ed.), German cultures, foreign cultures: The politics of belonging (pp. 1-16). Washington, DC: AICGS.

Putzke, H. (2008). Criminal relevance of circumcising boys: A contribution to the limitation of consent in cases of care for the person of the child (K. McLarren,
Trans.). Retrieved from http://www.holmputzke.de/ index.php/kontrovers/religioese-beschneidung

Schüklenk, U. (2012). Europe debates circumcision...but what about the child's best interests. Bioethics, 26(8), ii-iii.

Schwarze, T. (2012, October 1). Interview with R. Merkel: Ein kläglicher Gesetzentwurf. Die Zeit. Retrieved from http://www.zeit.de

Stehr, M. (2012, July 27). Unzumutbare Schmerzen. Der Spiegel. Retrieved from http://www.spiegel.de/spie gel/print/d-87482746.html

SZ. (2012, July 16). Schwerster Angriff auf jüdisches Leben seit dem Holocaust. Süddeutsche Zeitung (SZ). Retrieved from http://www.sueddeutsche.de

taz. (2012, August 21). Rabbiner will Medizinkurse. Retrieved from http://www.taz.de

Tosun, M. (2012, June 9). Sünnet Yapmayiz [We will not practice circumcision]. Hürriyet. Retrieved from http://www.hurriyet.com.tr/planet/20870182.asp

Vertovec, S., \& Wessendorf, S. (2006). Cultural, religious and linguistic diversity in Europe: An overview of issues and trends. In R. Penninx (Ed.), The dynamics of international migration and settlement in Europe (pp. 171-199). Amsterdam: AUP.

Yurdakul, G. (2010). Juden und Türken in Deutschland: Integration von Immigranten, Politische Repräsentation und Minderheitenrechte. In G. Yurdakul \& M. Bodemann, Staatsbürgerschaft, Migration und Minderheiten: Inklusion und Ausgrenzungstragien im Vergleich (pp. 127-160). Wiesbaden: Verlag Sozialwissenschaften.

Yurdakul, G. (2013). Ritual Male Circumcision, Muslim women's headscarves, forced marriages: What are the limits of minority accommodation in Germany? Paper presented at the Council for European Studies Conference, Amsterdam.

\section{About the Author}

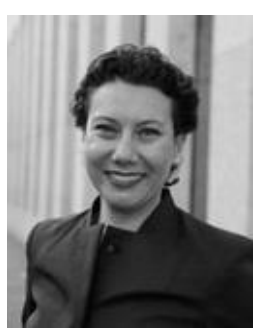

\section{Dr. Gökçe Yurdakul}

Gökçe Yurdakul is Georg Simmel Professor of Diversity and Social Conflict at the Humboldt University in Berlin and the co-chair of the Department on Foundations of Migration at the Berlin Institute of Migration and Integration Research. Her most recent book is The Headscarf debates: Conflict in national narratives (2014, Stanford University Press, with Anna Korteweg). She is currently conducting research on Contesting authorities over body politics: The religious/secular tension in Germany, Israel, and Turkey, funded by the German-Israeli Foundation (2016-2018, co-investigators with Shai Lavi). 